\title{
NON-COOPERATIVE TWO-ECHELON SUPPLY CHAINS WITH A FOCUS ON SOCIAL RESPONSIBILITY
}

\author{
Hannan AMOOZAD MAHDIRAJI ${ }^{1^{*}}$, Zenonas TURSKIS ${ }^{2}$, \\ Ahmad JAFARNEJAD ${ }^{3}$, Ali REZAYAR ${ }^{4}$ \\ ${ }^{1,3}$ Faculty of Management, University of Tehran, Tehran, Iran \\ ${ }^{2}$ Faculty of Civil Engineering, Vilnius Gediminas Technical University, Vilnius, Lithuania \\ ${ }^{4}$ Alborz Campus, University of Tehran, Tehran, Iran
}

Received 08 March 2019; accepted 01 May 2019

\begin{abstract}
To cooperate or not is one of the most challenging issues of supply chain management era. If the supply chain is managed optimally, the entire profitability increases. Meanwhile, corporate Social Responsibility (hereafter CSR) is defined as the social and ethical behavior of supply chain members against stakeholders such as shareholders, final customers, employees and executives. Moreover, the observance of the social responsibility obligations is of great importance for consumers and shareholders of companies. The decisions of the supply chain's members play a direct role in determining the profits of each. These decisions are in conflict with other members in a competitive environment.

In this paper, the contradictory variables encompasses the cost resulting from the performance of corporate social responsibility, inventory, shortage, advertising and pricing in a two-level supply chain, consisting a manufacturer and a retailer. After identifying the quantitative variables for measuring the social responsibility using Delphi-Fuzzy methods and Interpretive Structural Modeling, the most important and influential variable of measuring the social responsibility performance (forced labor ratio) has been selected. Subsequently, after modeling the profit function of each player, optimal results were emanated according to the bargaining power of each member and based on Nash and Stackelberg games. Afterwards, with numerical examples, the optimization and sensitivity analysis of social responsibility in each model has been discussed. The results indicate that the profit of manufacturer and retailer reduces by increasing the proportion of forced labor. Based upon Nash equilibrium, the manufacturer's profit decreases with a slight slope; nonetheless, on retailer and manufacturer leadership models, the profit decreases with a slight increase of the forced labor.
\end{abstract}

Keywords: supply chain management, Nash equilibrium, Stackelberg game, corporate social responsibility.

JEL Classification: C68, C72.

*Corresponding author. E-mail: h.amoozad@ut.ac.ir 


\section{Introduction}

Supply chain (henceforth SC) sustainability has three dimensions: economic, social and environmental. Sustainable supply chain management has been analyzed in various fields of economic activities: construction engineering and economic (Zavadskas, Šaparauskas, \& Antucheviciene, 2018; Akcay, Ergan, \& Arditi, 2017), infrastructure and construction projects development (Lopez, Chong, Moon, \& Wang, 2017; Ju, Ding, \& Skibniewski, 2017). CSR is one of the important and distinct dimensions in SC management (Hediger, 2010). Limited researches have performed in the field of social responsibility. The observance of the social responsibility obligations is very important for consumers and shareholders of companies (Ashby, Leat, \& Hudson-Smith, 2012). In response to this pressure, many members of the SC have created instructions to ensure that social responsibility is respected in the business operations of their partners (Debing, Kevin, \& Xiaowo, 2010). In fact, CSR leads to the creation of communication among stakeholders and it can be achieved by meeting the basic needs of stakeholders, employees, managers, customers, manufactures and suppliers (Maignan \& Ferrell, 2004).

For modeling the social responsibility in the SC, there is a need for quantitative measurable indicators rather than qualitative indicators. In addition to social responsibility, variables such as pricing, inventory, cost of deficiency and cost of advertising are contradictory to SC members.. In case the decisions are made according to the views of SC members, it is called the centralized decision-making approach. Using a centralized approach, an overall optimal solution can be achieved for all SC members; however, it may contradict the interests of some members. If the solution is not compatible with the interests of some members, they may refuse to enforce the decision.

There is a need for a coordination mechanism to create an overall optimal solution and minimize its contradiction with the interests of the members. Coordination models have mechanisms to motivate all members to pursue the overall optimal decisions and resolve the chain members' conflict.

Game theory solves the conflict between two or more players, regarding the payoff of each of them. If the power of bargaining among the players of the SC is equal, the game is Nash, and if one player is leader and the other is follower, the game is called Stackelberg. In this article, the manufacturer is responsible for the costs of social responsibility and the retailer is responsible for the costs of advertising and marketing the final product. Additionally, the costs of shortages and incremental behavior are considered for the manufacturer (Jia, Amoozad Mahdiraji, Govindan, \& Meidute, 2013). Therefore, considering the importance of coordination and conflict solution in the SC with regard to the social responsibility, this research has been designed to model and optimize the consequences of retailers and manufactures in complete information conditions. First of all, identifying the most beneficial variable in social responsibility performance evaluation of a supply chain has been scheduled. Afterwards, Based upon game theoretic approach and considered two echelon supply chain, Nash and Stackelberg equilibriums were calculated to optimize supply chain overall profit. Eventually, the emanated equilibriums were compared with each other on the basis of sensitivity analysis. 
The structure of the paper is as follows. Initially, an overview on the literature and background of previous researches in the field of corporate social responsibility measurements indicators, demand function, contradictory variables and SC games is illustrated. Next, the methodology of the research and modeling assumptions are reviewed. Afterwards, the symbols, the modeling of the outcome of each player, the concavity and the best responses of each member are examined. Eventually, the numerical example and the sensitivity analysis of social responsibility is discussed.

\section{Basic concepts and research background}

CSR is defined as the social and ethical behavior of supply chain's members against stakeholders such as shareholders, end customers, employees, and managers (Panda, 2014). In a more comprehensive definition, corporate social responsibility can be defined as follows (Working definition, ISO 26000 Working Group on Social Responsibility, 2007) "Social responsibility is a social and ethical behavior against stakeholders that enhances society's welfare and some standards have been edited for it through laws and guidelines."

Few researches have performed in the field of social responsibility and innovation in supply chains (Seuring \& Müller, 2008; Ashby et al., 2012; Ahi \& Searcy, 2015; Puška, Maksimović, \& Stojanović, 2018; Fazlollahtabar, 2018; Lukovac \& Popović, 2018). In SC modeling, quantitative and measurable variables are required to measure the CSR. There are various references for classifying the social responsibility indicators, including the Global Reporting Initiative (henceforth GRI), in which classes of labor practices, good and suitable work, human rights, product and social responsibility are considered. Several indicators have been investigated for quantitative measurement of social responsibility, some of which have been summarized in Table 1.

The demand function has been used to enter the Social Responsibility Measurement Index. In fact, demand is dependent on the manufacturer's social responsibility performance. Previous related researches and the type of demand functions have been presented in Table 2. For demand function at certain environments (C), for uncertain conditions (U), for linear type $(\mathrm{L})$ and for nonlinear functions $(\mathrm{N})$ is employed.

Note that $\mathrm{D}$ is demand, $\theta$ is fixed coefficient of demand function, $\alpha$ presents the price $(P)$ elasticity, $\beta$ denotes the effect of advertising costs $(C)$ and $\gamma$ measures the impact of corporate social responsibility (CSR) efforts. Remark that, similar researches in the area of social responsibility has been summarized in Table 3. 
Table 1. Quantitative indicators of social responsibility

\begin{tabular}{|c|c|}
\hline Research & Quantitative indicators examined \\
\hline \multirow{2}{*}{ (Azapagic \& Perdan, 2000) } & Income Distribution \\
\hline & Job Satisfaction \\
\hline \multirow{2}{*}{ (ICheme, 2002) } & Staff turnover \\
\hline & Promotion Rate \\
\hline \multirow{5}{*}{ (Szekely \& Knirsch, 2005) } & Crashes \\
\hline & Education \\
\hline & Gender ratio \\
\hline & Disabled employees \\
\hline & Collective bargaining agreements \\
\hline (Kruse, Flysjö, Kasperczyk, \& Scholz, 2009) & Working hours \\
\hline (de Bloom et al., 2009) & Vacation \\
\hline (Cascio, 2010) & Dismissal of employees \\
\hline \multirow[t]{2}{*}{ (Lim, Chan, \& Dallimore, 2010) } & $\begin{array}{l}\text { Full-time and part-time } \\
\text { employees }\end{array}$ \\
\hline & Years of service \\
\hline \multirow{2}{*}{ (GRI, 2011) } & Employee safety training \\
\hline & Indigenous rights \\
\hline (DPE, 2011) & Collective bargaining agreements \\
\hline \multirow[t]{2}{*}{ (Erol, Sencer, \& Sari, 2011) } & Discrimination \\
\hline & Staff complaints \\
\hline (Roca \& Searcy, 2012) & Unified staff \\
\hline (OECD, 2012) & Job Satisfaction \\
\hline (Klassen \& Vereecke, 2012) & Innovation \\
\hline \multirow{2}{*}{ (Caulier-Grice, Davies, Patrick, \& Norman, 2012) } & Innovation \\
\hline & New products \\
\hline (Hassini, Surti, \& Searcy, 2012) & Practices of stable suppliers \\
\hline (Uma, 2013) & Education \\
\hline (Katsikea, Theodosiou, \& Morgan, 2014) & Staff turnover \\
\hline (Kwon \& Milgrom, 2014) & Promotion Rate (Promotion) \\
\hline \multirow{3}{*}{ (Mani, Agrawal, \& Sharma, 2014) } & Wage level Between Sexes \\
\hline & Labor Children \\
\hline & forced labor of labor forces \\
\hline (European Commission, 2014) & New products \\
\hline (Jong \& Slavova, 2014) & Scientific publication \\
\hline \multirow{2}{*}{ (Podgorski, 2015) } & Risk Assessment \\
\hline & Risk control implementation \\
\hline (Simoes, Freitas, Barbosa-Povoa, \& Carvalho, 2016) & Staff turnover \\
\hline $\begin{array}{l}\text { (T. Strandberg, von Bonsdorff, A. Strandberg, Pitkala, \& } \\
\text { Raikkonen, 2017) }\end{array}$ & Vacation \\
\hline
\end{tabular}


Table 2. Demand functions employed in supply chains

\begin{tabular}{|c|c|c|c|c|}
\hline Scholar, year & $\begin{array}{l}\text { Demand } \\
\text { Function } \\
\text { Certainty }\end{array}$ & $\begin{array}{c}\text { Demand } \\
\text { function } \\
\text { Type }\end{array}$ & Examined variables & Demand equation \\
\hline Goering, 2012 & $\mathrm{C}$ & $\mathrm{L}$ & Price & $D=a-b p-w$ \\
\hline $\begin{array}{l}\text { Ma, Wang, \& Shang, } \\
2013\end{array}$ & $\mathrm{C}$ & $\mathrm{L}$ & $\begin{array}{l}\text { Price, Marketing, } \\
\text { CSRCSR }\end{array}$ & $D=a-b p+\gamma e+\mathfrak{E} y$ \\
\hline Panda, 2014 & $\mathrm{C}$ & $\mathrm{L}$ & Price & $D(p)=a-b p$ \\
\hline $\begin{array}{l}\text { Modak, Panda, Sana, } \\
\text { \& Basu, } 2014\end{array}$ & $\mathrm{C}$ & $\mathrm{L}$ & Price & $D_{r}=\theta a-b p_{r}+\propto\left(p_{d}-p_{r}\right)$ \\
\hline $\begin{array}{l}\text { Panda, Modak, Basu, } \\
\text { \& Goyal, } 2015\end{array}$ & $\mathrm{C}$ & $\mathrm{L}$ & Price & $D(p)=a-b p$ \\
\hline $\begin{array}{l}\text { Modak, Panda, } \\
\text { Mishra, \& Sana, } \\
2016\end{array}$ & $\mathrm{C}$ & $\mathrm{L}$ & Price & $D(p)=a-b p$ \\
\hline Modak et al., 2016 & $\mathrm{C}$ & $\mathrm{L}$ & Price & $D_{i j}^{r}=a_{i j}-b p_{i j}^{r}+\theta\left(p-p_{i j}^{r}\right)$ \\
\hline $\begin{array}{l}\text { Panda, Modak, \& } \\
\text { Cárdenas-Barrón, } \\
2017\end{array}$ & $\mathrm{C}$ & $\mathrm{L}$ & Price & $D(p)=a-b p$ \\
\hline $\begin{array}{l}\text { Nematollahia, } \\
\text { Hosseini-Motlagha, } \\
\text { \& Heydarib, } 2017\end{array}$ & $\mathrm{U}$ & $\mathrm{L}$ & CSRCSR & $\left(\mu_{0}+a g(\varepsilon)\right)$ \\
\hline $\begin{array}{l}\text { Raj, Biswas, \& } \\
\text { Srivastava, } 2018\end{array}$ & $\mathrm{U}$ & $\mathrm{L}$ & CSRCSR & $\left(\mu_{0}+a y\right)$ \\
\hline $\begin{array}{l}\text { Amoozad Mahdiraji, } \\
\text { Shateri, Beheshti, \& } \\
\text { Mokhtarzadeh, } 2019\end{array}$ & $\mathrm{U}$ & $\mathrm{N}$ & Re Order Point (ROP) & $\frac{e^{-\lambda \star \lambda^{x}}}{x !}$ \\
\hline $\begin{array}{l}\text { Features of this } \\
\text { research }\end{array}$ & $\mathrm{C}$ & $\mathrm{N}$ & $\begin{array}{l}\text { Price, Marketing, } \\
\text { Social Responsibility } \\
\text { Index }\end{array}$ & $D=\theta \cdot P^{-\alpha} \cdot C^{\beta} \cdot C S R^{\gamma}$ \\
\hline
\end{tabular}

Table 3. Related Research background

\begin{tabular}{|c|c|c|c|c|c|c|c|}
\hline \multirow[b]{2}{*}{ Scholar, Year } & \multirow[b]{2}{*}{ Echelon } & \multirow[b]{2}{*}{$\begin{array}{l}\text { Type of } \\
\text { demand }\end{array}$} & \multicolumn{2}{|c|}{ Type of game } & \multirow[b]{2}{*}{$\begin{array}{l}\text { short- } \\
\text { ages } \\
\text { included }\end{array}$} & \multirow[b]{2}{*}{$\begin{array}{c}\text { Scale } \\
\text { advantage } \\
\text { included }\end{array}$} & \multirow[b]{2}{*}{$\begin{array}{l}\text { Variables } \\
\text { included }\end{array}$} \\
\hline & & & $\begin{array}{l}\text { Coop- } \\
\text { erative }\end{array}$ & $\begin{array}{l}\text { Non-Co- } \\
\text { operative }\end{array}$ & & & \\
\hline $\begin{array}{l}\mathrm{Ni}, \mathrm{Li}, \& \\
\text { Tang, } 2010\end{array}$ & 2 & $\begin{array}{l}\text { price- } \\
\text { dependent }\end{array}$ & $\nabla$ & 田 & 冈 & 冈 & $\begin{array}{l}\text { social } \\
\text { responsibility }\end{array}$ \\
\hline $\begin{array}{l}\text { Goering, } \\
2012\end{array}$ & 2 & $\begin{array}{l}\text { price- } \\
\text { dependent }\end{array}$ & $\square$ & $\boldsymbol{x}$ & 凶 & 凶 & $\begin{array}{l}\text { Price, Order, } \\
\text { Social } \\
\text { Responsibility }\end{array}$ \\
\hline $\begin{array}{l}\text { Modak } \\
\text { et al., } 2014\end{array}$ & 2 & $\begin{array}{l}\text { Price, } \\
\text { advertising, } \\
\text { CSRCSR } \\
\text { dependent } \\
\end{array}$ & $\square$ & $\boldsymbol{x}$ & 凶 & 冈 & $\begin{array}{l}\text { Price, Order, } \\
\text { Social } \\
\text { Responsibility }\end{array}$ \\
\hline Hsueh, 2014 & 2 & $\begin{array}{l}\text { CSRCSR- } \\
\text { dependent }\end{array}$ & 冈 & $\nabla$ & 冈 & 凶 & $\begin{array}{l}\text { social } \\
\text { responsibility }\end{array}$ \\
\hline
\end{tabular}


End of Table 3

\begin{tabular}{|c|c|c|c|c|c|c|c|}
\hline \multirow[b]{2}{*}{ Scholar, Year } & \multirow[b]{2}{*}{ Echelon } & \multirow[b]{2}{*}{$\begin{array}{l}\text { Type of } \\
\text { demand }\end{array}$} & \multicolumn{2}{|c|}{ Type of game } & \multirow{2}{*}{$\begin{array}{c}\text { short- } \\
\text { ages } \\
\text { included }\end{array}$} & \multirow{2}{*}{$\begin{array}{c}\text { Scale } \\
\text { advantage } \\
\text { included }\end{array}$} & \multirow[b]{2}{*}{$\begin{array}{l}\text { Variables } \\
\text { included }\end{array}$} \\
\hline & & & $\begin{array}{l}\text { Coop- } \\
\text { erative }\end{array}$ & $\begin{array}{l}\text { Non-Co- } \\
\text { operative }\end{array}$ & & & \\
\hline Panda, 2014 & 2 & $\begin{array}{l}\text { Certain } \\
\text { price- } \\
\text { dependent }\end{array}$ & $\nabla$ & 冈 & 冈 & 凶 & $\begin{array}{l}\text { social } \\
\text { responsibility }\end{array}$ \\
\hline $\begin{array}{l}\text { Panda et al., } \\
2015\end{array}$ & 3 & $\begin{array}{l}\text { price- } \\
\text { dependent }\end{array}$ & 冈 & $\nabla$ & 冈 & 凶 & $\begin{array}{l}\text { social } \\
\text { responsibility }\end{array}$ \\
\hline Panda, 2016 & 2 & $\begin{array}{l}\text { price- } \\
\text { dependent }\end{array}$ & 冈 & $\nabla$ & 冈 & 冈 & $\begin{array}{l}\text { social } \\
\text { responsibility }\end{array}$ \\
\hline Panda, 2016 & 2 & $\begin{array}{l}\text { price- } \\
\text { dependent }\end{array}$ & $\nabla$ & 冈 & 冈 & 凶 & \begin{tabular}{|l|} 
social \\
responsibility
\end{tabular} \\
\hline $\begin{array}{l}\text { Nematollahia } \\
\text { et al., } 2017\end{array}$ & 2 & Stochastic & 冈 & $\nabla$ & 冈 & 凶 & $\begin{array}{l}\text { Social } \\
\text { responsibility, } \\
\text { Order }\end{array}$ \\
\hline $\begin{array}{l}\text { Panda et al., } \\
2017\end{array}$ & 2 & $\begin{array}{l}\text { attempt on } \\
\text { recycling- } \\
\text { dependent }\end{array}$ & $\nabla$ & 凶 & 冈 & 冈 & $\begin{array}{l}\text { Price, Order, } \\
\text { Social } \\
\text { Responsibility }\end{array}$ \\
\hline $\begin{array}{l}\text { Raj et al., } \\
2018\end{array}$ & 2 & $\begin{array}{l}\text { price and } \\
\text { green } \\
\text { CSRCSR- } \\
\text { dependent }\end{array}$ & $\boldsymbol{x}$ & $\nabla$ & 冈 & 冈 & $\begin{array}{l}\text { Price, order } \\
\text { quantity, social } \\
\text { responsibility, } \\
\text { green level }\end{array}$ \\
\hline $\begin{array}{l}\text { Features of } \\
\text { this research }\end{array}$ & 2 & $\begin{array}{l}\text { price, } \\
\text { advertising } \\
\text { and } \\
\text { CSRCSR- } \\
\text { dependent }\end{array}$ & $\boldsymbol{x}$ & $\nabla$ & $\nabla$ & $\nabla$ & $\begin{array}{l}\text { Price, Inventory, } \\
\text { Advertising, } \\
\text { Social } \\
\text { Responsibility }\end{array}$ \\
\hline
\end{tabular}

\section{Methodology and research assumptions}

\subsection{Research assumptions}

1. The SC has a knowledgeable manufacturer and retailer and the manufacturer sells its product to the retailer;

2. The demand is dependent on price, promotional costs and social responsibility performance cost;

3. Shortage cost is considered per unit of shortage. This fee is intended for the manufacturer;

4. The scale advantage and the incremental behavior are supposed in the production.

5. Decision variables include inventory, shortage, pricing, marketing costs and the performance of social responsibility;

6. Optimal policies have been explored in non-cooperative static (Nash) and continuous dynamic (Stackelberg) modes;

7. The planning horizon is unlimited and the game is non-repetitive;

8. A single product is produced and sent to a retailer;

9. The status of players' information is considered complete, that is, both players are fully aware of the strategies, outcomes and movements of each other; 
10. The retailer is responsible for the advertising cost and the manufacturer is responsible for the social responsibility cost.

\subsection{Research methodology}

The methodology of this paper consists of numerous steps in four phases presented below.

(1) Literature review. First of all, by studying the background of the research, variables related to sustainability and social responsibility have been gathered. Secondly, variables are categorized quantitatively and qualitatively according to groups related to sustainability and social responsibility. Note that, the basis of this study is those variables that are quantitative and measurable by mathematical relations.

(2) Delphi Fuzzy. Next, the Delphi-Fuzzy questionnaire with a scale of 1 to 10 grade was designed for the second stage variables and distributed among experts and specialists and its results were analyzed. The fourth step involves the selection of high convergence variable from Delphi-Fuzzy method and the formation of a structural self-interactive matrix and distribution of its questionnaire among experts and specialists.

(3) Interpretive Structural Modeling. After gathering the experts' opinions, the formation of the initial reachability matrix is studied. Subsequently, designing the final reachability matrix; determining the relations and leveling indicators; modeling the network of interactions and analyzing the power of influence and degree of dependence used in the interpretive and structural analysis are applied.

(4) Optimization based on game theory. Afterwards, modeling, optimization and numerical examples of non-cooperative models of Nash and Stackelberg are discussed.

\section{Phase 1) Literature review}

In this paper, upon Popovich et al. research (Popovic, Povoa, Kraslawski, \& Carvalho, 2018) 31 quantitative indicators of social responsibility measurement have been examined in nine categories as Table 4.

Table 4. Quantitative indexes in corporate social responsibility

\begin{tabular}{|l|l|}
\hline \multicolumn{1}{|c|}{ Main Index } & \multicolumn{1}{c|}{ Definition/Sub Criteria's } \\
\hline $\begin{array}{l}\text { Employment benefits and } \\
\text { characteristics }\end{array}$ & $\begin{array}{l}\text { Employee turnover, Employee layoffs, Working hours, } \\
\text { Full- and part-time employees, Years of service }\end{array}$ \\
\hline Employment practices and relations & Promotion rate, Unionized employees \\
\hline $\begin{array}{l}\text { Health and safety (H\&S) practices } \\
\text { and incidents }\end{array}$ & $\begin{array}{l}\text { Time lost, Accidents, Risk assessment, Healthcare security } \\
\text { coverage, Implementation of risk control }\end{array}$ \\
\hline $\begin{array}{l}\text { Training, education, and personal } \\
\text { skills }\end{array}$ & Training, Education level \\
\hline $\begin{array}{l}\text { Diversity and equal opportunities } \\
\text { employees, Income distribution }\end{array}$ & Ratio of genders, Wage level between genders, Disabled \\
\hline Employee welfare & Vacation, Work satisfaction \\
\hline Innovation and competitiveness & Innovations, New products, Scientific publications \\
\hline $\begin{array}{l}\text { Human rights implementation } \\
\text { and integration }\end{array}$ & $\begin{array}{l}\text { Personnel security training, Child labor, Bonded labor, } \\
\text { Collective bargaining agreements, Sustainable suppliers practice }\end{array}$ \\
\hline Basic human rights practice & Discrimination, Employee complaints, Rights of indigenous people \\
\hline
\end{tabular}




\section{Phase 2) Fuzzy-Delphi method}

1. Identifying the quantitative indicators for measuring the corporate social responsibility;

2. Designing a questionnaire in which expert's weigh identified factors in the range of 1 to 10. Therefore, for each of the identified factors in the first stage, score state as Equation (1):

$$
C_{i k}=\left(L_{i k}, U_{i k}\right) \text {, }
$$

where $L_{i k}$ is the most pessimistic score of $\mathrm{k}_{\mathrm{th}}$ expert given to $\mathrm{i}_{\mathrm{th}}$ criteria, similarly $U_{i k}$ is the most optimistic score.

3. At this stage, the geometric mean of the most pessimistic and optimistic scores given by the respondent $\mathrm{k}$ to $\mathrm{i}_{\text {th }}$ criteria has been calculated by Equation (2):

$$
g_{i k}=\sqrt{L_{i k} \times U_{i k}} \text {. }
$$

Therefore, for $i_{\text {th }}$ criteria, by $k_{\text {th }}$ expert, related score is resulted from Equation (3):

$$
C_{i k}=\left(L_{i k}, g_{i k}, U_{i k}\right) \text {. }
$$

4. The geometric mean and standard deviation of the most pessimistic and optimistic scores were emanated. Afterwards, the scores that are out of the range \pm 2 std were eliminated. Next, from the most pessimistic remaining scores, the lowest value $C_{l}^{i}$, the maximum value $C_{u}^{i}$ and the geometric mean $C_{m}^{i}$ has been calculated. Similarly, the lowest value of $O_{l}^{i}$, the maximum value of $O_{u}^{i}$ and the geometric mean of $O_{m}^{i}$ were resulted.

5. For the agent $i$, the most pessimistic index $C^{i}$ and the most optimistic index $O^{i}$ are calculated as Equations (4) and (5):

$$
\begin{aligned}
& C^{i}=\left(C_{l}^{i}, C_{m}^{i}, C_{u}^{i}\right) ; \\
& O^{i}=\left(O_{l}^{i}, O_{m}^{i}, O_{u}^{i}\right) .
\end{aligned}
$$

6. The consensus of the expert's answers were examined. One of the following three situations can be occurred.

- If there is no cover between two fuzzy triangle numbers $\left(C_{u}^{i} \leq O_{l}^{i}\right)$, there is an agreement on the agent $\mathrm{i}$ among the respondents and the meaningful consensus amount is calculated as Equation (6):

$$
G^{i}=\frac{C_{m}^{i}+O_{m}^{i}}{2}
$$

- If there is a coverage area between the two fuzzy triangle numbers (for example $\left(C_{u}^{i}>O_{l}^{i}\right)$, then the value of the geometric mean distance $M^{i}$ and the value of the gray region distance $Z^{i}$ should be obtained using following Equations (7) and (8):

$$
\begin{aligned}
M^{i} & =O_{m}^{i}-C_{m}^{i} ; \\
Z^{i} & =C_{u}^{i}-O_{l}^{i} .
\end{aligned}
$$

- If $Z^{i} \leq M^{i}$, the meaningful amount of the consensus of the experts $G^{i}$ is calculated by Equation (9):

$$
G^{i}=\frac{\left[\left(C_{u}^{i} \times O_{m}^{i}\right)-\left(O_{l}^{i} \times C_{m}^{i}\right)\right]}{\left[\left(C_{u}^{i}-C_{m}^{i}\right)+\left(O_{m}^{i}-O_{l}^{i}\right)\right]}
$$


If $Z^{i}>M^{i}$, there is a great deal of difference between the opinion of the experts and the steps should be repeated until convergence is achieved.

In the final step, the threshold value of $(S)$ for extracting the essential factors from the list of potential agents were determined. Note that, there are essentially no identical and standard methods for determining the threshold value; however, in some cases the threshold value is considered based on / (80-20) law. If $G^{i} \geq S, \mathrm{i}_{\text {th }}$ criterion is selected for further analysis (Kuo \& Chen, 2008; Hanafizadeh \& Mirzazadeh, 2011).

Considering aforementioned procedure, nine variables embracing accidents, security coverage, gender ratio, pay level between genders, disabled workers, income distribution, child labor, forced labor and discrimination were selected as the final indicators of the experts in the Fuzzy-Delphi method.

\section{Phase 3) Interpretive Structural-Modeling}

The Interpretative Structural-Modeling Technique (henceforth ISM) was first developed by Warfield in 1973. Since then, it has been widely used in various decision making areas. This technique gives the decision maker the ability to formulate a variety of relevant elements in a comprehensive systematic model. The ISM technique, by utilizing the experience and knowledge of related professionals, divides a complex system into several different subsystems, and in this way, it discovers the independent or interdependent relationships among the existing elements in the system (Chen $\& \mathrm{Wu}, 2010)$ ISM technique steps are as follows.

Step 1. Identifying the variables related to the question.

Step 2. Creating Structural Interactive Matrix. This stage leads to analysis by following symbols to determine the relationships between variables.

$\mathrm{V}$ : This means that the index $\mathrm{i}$ leads to $\mathrm{j}$.

A: This means that the index $j$ leads to $i$.

$\mathrm{X}$ : To illustrate the two-way effect

O: To indicate the absence of a relationship between the two indicators

Step 3. Creating an Initial Reachability Matrix. In order to replace the numbers zero and one instead of the four symbols of the above table, the following rules are used to extract the initial reachability matrix.

- If input $(i, j)$ in the structural self-interactive matrix is $v$, then place 1 in $(i, j)$ and 0 in $(j, i)$;

- If input $(i, j)$ in the structural self-interactive matrix is $A$, then place 0 in $(i, j)$ and 1 in $(j, i)$;

- If input $(i, j)$ in the structural self-interactive matrix is $X$, then place $1 \mathrm{in}(i, j)$ and 1 in $(j, i)$;

- If input $(i, j)$ in the structural self-interactive matrix is $O$, then place 0 in $(i, j)$ and 0 in $(j, i)$;

- If $\mathrm{i}=\mathrm{j}, 1$ is placed in the initial reachability matrix. The results are shown at the following Table 5 and 6 (Azar, Khosravani, \& Jalal, 2013).

Step 4. Creating the Final Reachability Matrix. If $(i, j)$ are interconnected and $(j, k)$ are interconnected, then (i, k) are interconnected. 
Step 5. Determining the Relationships and Leveling the Indicators. In this step, using the final reachability matrix, after assigning input and output sets, it is possible to share these sets for each of the barriers.

Step 6. Drawing an Interactions Network Model. In this stage, the final model is obtained according to the levels of the indicators and the final reachability matrix and through the elimination of secondary relationships and in the interpretive structural modeling, this figure is called the structural or diagraph model.

Step 7. Analyzing the power of penetration and the degree of dependency. At this stage, the variables are classified into four groups. The first group consists of autonomous variables (region 1) with weak influence. The second group includes dependent variables (region 2) that have a weak influence but a high dependence. The third group is the transplant variables (region 3). These variables have a high degree of influence. In fact, any action on these variables leads to a change in other variables. The fourth group is the independent variables (area 4) (Azar et al., 2013).

Considering the statistical fashion of the faculty members' viewpoints, the self- interactive structural matrix is as follows. The initial reachability matrix is obtained by converting a structural self-interactive matrix to a two-value matrix (zero and one). The results are presented in Table 5. In order to achieve the ultimate reachability matrix, after the initial reachability matrix is obtained, its internal consistency should be established; accordingly, the result are demonstrated in the Tables 6, 7 and 8. Remark that, the numbers marked ${ }^{\star}$ are shown to be zero in the original matrix and converted to one after compatibility.

Table 5. Structural self-interactive matrix

\begin{tabular}{|c|c|c|c|c|c|c|c|c|c|}
\hline 9 & 8 & 7 & 6 & 5 & 4 & 3 & 2 & 1 & Index \\
\hline 0 & 0 & 0 & 0 & 1 & 0 & 0 & 1 & 1 & 1 \\
\hline 1 & 1 & 0 & 0 & 0 & 0 & 0 & 1 & 1 & 2 \\
\hline 1 & 0 & 0 & 1 & 0 & 1 & 1 & 0 & 0 & 3 \\
\hline 1 & 0 & 0 & 1 & 0 & 1 & 1 & 1 & 0 & 4 \\
\hline 0 & 0 & 0 & 0 & 1 & 0 & 0 & 0 & 0 & 5 \\
\hline 1 & 1 & 0 & 1 & 0 & 1 & 0 & 1 & 1 & 6 \\
\hline 1 & 0 & 1 & 0 & 0 & 0 & 0 & 0 & 1 & 7 \\
\hline 1 & 1 & 0 & 0 & 1 & 0 & 0 & 0 & 0 & 8 \\
\hline 1 & 0 & 0 & 1 & 0 & 1 & 1 & 0 & 0 & 9 \\
\hline
\end{tabular}

Table 7. Final Reachability Matrix

\begin{tabular}{|c|c|c|c|c|c|c|c|c|c|}
\hline 9 & 8 & 7 & 6 & 5 & 4 & 3 & 2 & 1 & Index \\
\hline 0 & $1^{*}$ & 0 & 0 & 1 & $1^{\star}$ & 0 & 1 & 1 & 1 \\
\hline 1 & 1 & $1^{*}$ & $1^{\star}$ & 0 & $1^{\star}$ & $1^{*}$ & 1 & 1 & 2 \\
\hline 1 & $1^{*}$ & $1^{*}$ & 1 & 0 & 1 & 1 & 0 & 0 & 3 \\
\hline 1 & $1^{*}$ & $1^{*}$ & 1 & 0 & 1 & 1 & 1 & $1^{*}$ & 4 \\
\hline 0 & 0 & 0 & 0 & 1 & 0 & 0 & 0 & 0 & 5 \\
\hline 1 & 1 & $1^{*}$ & 1 & 0 & 1 & $1^{\star}$ & 1 & 1 & 6 \\
\hline 1 & $1^{*}$ & 1 & $1^{\star}$ & 0 & $1^{*}$ & $1^{\star}$ & $1^{*}$ & 1 & 7 \\
\hline 1 & 1 & $1^{*}$ & $1^{\star}$ & 1 & $1^{*}$ & $1^{*}$ & $1^{*}$ & $1^{*}$ & 8 \\
\hline 1 & 0 & 0 & 1 & 0 & 1 & 1 & 0 & 0 & 9 \\
\hline
\end{tabular}

Table 6. Initial reachability matrix

\begin{tabular}{|c|c|c|c|c|c|c|c|c|c|}
\hline 9 & 8 & 7 & 6 & 5 & 4 & 3 & 2 & 1 & Index \\
\hline O & O & A & A & V & O & O & X & & 1 \\
\hline V & V & O & A & O & A & O & & & 2 \\
\hline X & O & O & V & O & X & & & & 3 \\
\hline X & O & O & X & O & & & & & 4 \\
\hline O & A & O & O & & & & & & 5 \\
\hline X & V & O & & & & & & & 6 \\
\hline V & O & & & & & & & & 7 \\
\hline V & & & & & & & & & 8 \\
\hline & & & & & & & & & 9 \\
\hline
\end{tabular}

Table 8. Determining the Relationships and Leveling of Indicators

\begin{tabular}{|c|c|c|}
\hline Level & index & Repeat \\
\hline 2 & 1 & 2 \\
\hline 2 & 2 & 2 \\
\hline 1 & 3 & 1 \\
\hline 1 & 4 & 1 \\
\hline 1 & 5 & 1 \\
\hline 3 & 6 & 3 \\
\hline 3 & 7 & 3 \\
\hline 2 & 8 & 2 \\
\hline 1 & 9 & 1 \\
\hline
\end{tabular}




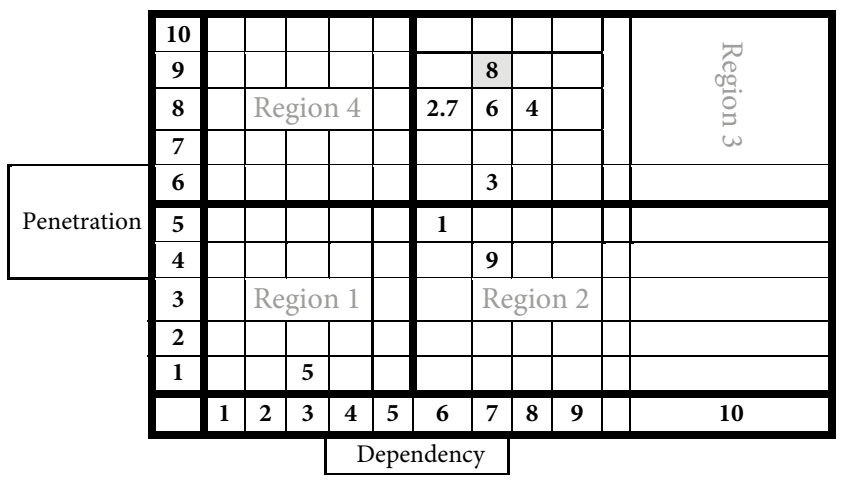

Figure 1. Penetration power and dependency degree Matrix

In order to find the forming components of system's next level, its highest components are eliminated in the corresponding table calculations and operations related to determining the next level components are performed like the method for determining the highest-level components. In the next step, the interaction network model has been plotted. At this stage, the final model is obtained according to the level of the indexes and the final reachability matrix, and by eliminating the secondary relations, which is called structured or diagraph modeling in Figure 1.

Obviously, no variables are located in area 4 . Indicators $1,2,3,4,6,8$ are located in area 3 (Linked) and have the highest penetration and maximum dependency. Indicator 9 is located in Zone 2 and has high dependence and medium penetration. Indicator 5 is in zone 1 and has the lowest degree of dependency influence. As in the penetration-power matrix, the index of discrimination (racial, sexual, discrimination against the disabled, harassment, and violence) is in the area of dependency, indicating the low power of influence; nonetheless, the high degree of dependency toward other indices. Accidents' indicators, number of reported accidents per year, health coverage, number of employees with social security, health insurance, sex ratio between male and female employees, level of payment between genders, income distribution among employees and forced labor factors indicate high dependency and penetration power, all of which are key indicators for measuring the sustainability and social responsibility.

Among the key indicators, forced labor as the most influential indicator should be considered by the supply chain members more than others. Moreover, due to high dependency in this area, any action on these indicators changes other indicators. Forced labor $\left(B L_{\text {ratio }}\right)$ is the registered percentage of forced labor in the supply chain (Mani et al., 2014). In the next sections, this index has been included in the supply chain models through the demand function based on Table 9.

In the Equation (10), $B L$ is the number of registered labor in institution. $N_{\text {tot }}$ denotes the total number of employees of the company. 
Table 9. Selected index description

\begin{tabular}{|l|l|}
\hline \multicolumn{1}{|c|}{ ID } & \multicolumn{1}{c|}{$B L_{\text {ratio }}$} \\
\hline Descriptions & Registered percent of the forced labor working in the supply chain \\
\hline Formula & $B L_{\text {ratio }}=\frac{B L}{N_{\text {tot }}} \times 100$ \\
\hline Unit of measure & Percentage \\
\hline Measuring range & Minimum 0 and maximum $100 \%$ \\
\hline Process & less, better \\
\hline Scale & Whole supply chain, entity \\
\hline Scheduling & Periodically based on demand \\
\hline Audiences & Management \\
\hline Additional explanation & This indicator, like child labor, should be part of external auditing \\
\hline
\end{tabular}

\subsection{Phase 4) Mathematical modeling}

\subsubsection{Notations}

Table 10 describes the functions, parameters and variables that are related to the modeling of the retailers' outcomes. $\mathrm{R}$ stands for the retailer and $\mathrm{M}$ indicates the wholesaler. Note that, (F) stands for functions, (V) for decision variable and (P) for parameters.

Table 10. Retailer and manufacturer notations

\begin{tabular}{|c|c|l|c|c|l|}
\hline Symbol & Type & \multicolumn{1}{|c|}{ Description } & Symbol & Type & \multicolumn{1}{|c|}{ Description } \\
\hline $\mathrm{G}_{\mathrm{R}}$ & $\mathrm{F}$ & Retailers Profit Margin & $\mathrm{TC}_{\mathrm{M}}$ & $\mathrm{F}$ & $\begin{array}{l}\text { Manufacturers Total } \\
\text { Costs }\end{array}$ \\
\hline $\mathrm{D}$ & $\mathrm{F}$ & Demand Function & $\pi_{\mathrm{M}}$ & $\mathrm{F}$ & $\begin{array}{l}\text { Manufacturers Payoff/ } \\
\text { Profit Function }\end{array}$ \\
\hline $\mathrm{C}_{\mathrm{R}}$ & $\mathrm{V}$ & Retailers Marketing costs & $\mathrm{PC}_{\mathrm{M}}$ & $\mathrm{P}$ & $\begin{array}{l}\text { Manufacturers } \\
\text { Production Capacity }\end{array}$ \\
\hline $\mathrm{C}_{\mathrm{O}_{\mathrm{R}}}, \beta, \gamma$ & $\mathrm{P}$ & $\begin{array}{l}\text { Demand function coefficient of } \\
\text { price elasticity, advertising and } \\
\text { Social responsibility coefficient }\end{array}$ & $\mathrm{C}_{\mathrm{SM}}$ & $\mathrm{P}$ & $\begin{array}{l}\text { Manufacturers Setup } \\
\text { Cost }\end{array}$ \\
\hline $\mathrm{Q}_{\mathrm{R}}$ & $\mathrm{V}$ & Retailers Ordering Costs & $\mathrm{u}_{\mathrm{M}}$ & $\mathrm{P}$ & $\begin{array}{l}\text { Manufacturers } \\
\text { Production Cost }\end{array}$ \\
\hline $\mathrm{C}_{\mathrm{h}_{\mathrm{R}}}$ & $\mathrm{P}$ & Retailers Holding Costs & $\mathrm{C}_{\mathrm{h}_{\mathrm{M}}}$ & $\mathrm{P}$ & $\begin{array}{l}\text { Manufacturers Holding } \\
\text { Cost }\end{array}$ \\
\hline $\mathrm{TR}_{\mathrm{R}}$ & $\mathrm{F}$ & Retailers Total Revenue & $\mathrm{B}_{\mathrm{M}}$ & $\mathrm{V}$ & Manufacturer Shortage \\
\hline $\mathrm{TMC}_{\mathrm{R}}$ & $\mathrm{F}$ & Retailers Total Marketing Costs & $\mathrm{C}_{\mathrm{B}_{\mathrm{M}}}$ & $\mathrm{P}$ & $\begin{array}{l}\text { Manufacturer Backlog } \\
\text { Cost }\end{array}$ \\
\hline $\mathrm{TOC}_{\mathrm{R}}$ & $\mathrm{F}$ & Retailers Total Ordering Costs & $\mathrm{C}_{\mathrm{P}_{\mathrm{M}}}$ & $\mathrm{P}$ & $\begin{array}{l}\text { Manufacturers } \\
\text { Purchase Cost }\end{array}$ \\
\hline
\end{tabular}


End of Table 10

\begin{tabular}{|c|c|l|c|c|l|}
\hline Symbol & Type & \multicolumn{1}{|c|}{ Description } & Symbol & Type & \multicolumn{1}{|c|}{ Description } \\
\hline $\mathrm{THC}_{\mathrm{R}}$ & $\mathrm{F}$ & Retailers Total Holding Costs & $\mathrm{C}_{\mathrm{L}_{\mathrm{M}}}$ & $\mathrm{P}$ & $\begin{array}{l}\text { Manufacturers Unit } \\
\text { Production Costs }\end{array}$ \\
\hline $\mathrm{TC}_{\mathrm{R}}$ & $\mathrm{F}$ & Retailers Total Costs & $\mathrm{TO}_{\mathrm{M}}$ & $\mathrm{F}$ & $\begin{array}{l}\text { Manufacturers Total } \\
\text { Ordering Cost }\end{array}$ \\
\hline$\pi_{\mathrm{R}}$ & $\mathrm{F}$ & Retailers Profit/Payoff Function & $\mathrm{TS}_{\mathrm{M}}$ & $\mathrm{F}$ & $\begin{array}{l}\text { Manufacturers Total } \\
\text { Setup Costs }\end{array}$ \\
\hline $\mathrm{L}_{\text {totM }}$ & $\mathrm{P}$ & Total number of employees & $\mathrm{TRC}_{\mathrm{M}}$ & $\mathrm{F}$ & $\begin{array}{l}\text { Manufacturers Total } \\
\text { Related Costs }\end{array}$ \\
\hline $\mathrm{BL}_{\mathrm{M}}$ & $\mathrm{P}$ & $\begin{array}{l}\text { The number of registered labor } \\
\text { work force }\end{array}$ & $\varphi_{\mathrm{M}}$ & $\mathrm{F}$ & $\begin{array}{l}\text { Demand ratio upon } \\
\text { manufacturer capacity }\end{array}$ \\
\hline $\mathrm{BL}_{\mathrm{ratio}}$ & $\mathrm{F}$ & $\begin{array}{l}\text { Labor Income Index for } \\
\text { Measuring Social Responsibility }\end{array}$ & $\eta_{\mathrm{M}}$ & $\mathrm{P}$ & $\begin{array}{l}\text { Social responsibility } \\
\text { costs for each unit }\end{array}$ \\
\hline $\mathrm{CSR}_{\mathrm{M}}$ & $\mathrm{F}$ & $\begin{array}{l}\text { Social Responsibility } \\
\text { Measurement Index }\end{array}$ & $\mathrm{TR}_{\mathrm{M}}$ & $\mathrm{F}$ & $\begin{array}{l}\text { Total Manufacturers } \\
\text { Revenue }\end{array}$ \\
\hline $\mathrm{PC}_{\mathrm{M}}$ & $\mathrm{P}$ & $\begin{array}{l}\text { Manufacturers Production } \\
\text { Capacity }\end{array}$ & $\mathrm{TBC}_{\mathrm{M}}$ & $\mathrm{F}$ & $\begin{array}{l}\text { Total Backlog/ } \\
\text { Shortage costs }\end{array}$ \\
\hline $\mathrm{G}_{\mathrm{M}}$ & $\mathrm{F}$ & Manufacturers Profit Margin & $\mathrm{TOSC}_{\mathrm{M}}$ & $\mathrm{F}$ & $\begin{array}{l}\text { Manufacturers Total } \\
\text { Ordering and Setup } \\
\text { Costs }\end{array}$ \\
\hline $\mathrm{P}_{\mathrm{R}}$ & $\mathrm{P}$ & Retailers Price & $\mathrm{THC}_{\mathrm{M}}$ & $\mathrm{F}$ & $\begin{array}{l}\text { Manufacturers Total } \\
\text { Holding Costs }\end{array}$ \\
\hline $\mathrm{P}_{\mathrm{M}}$ & $\mathrm{V}$ & Manufacturers Wholesale Price & $\mathrm{TPC}_{\mathrm{M}}$ & $\mathrm{F}$ & $\begin{array}{l}\text { Manufacturers Total } \\
\text { Production Costs }\end{array}$ \\
\hline $\mathrm{C}_{\mathrm{O}_{\mathrm{M}}}$ & $\mathrm{P}$ & Manufacturer Ordering Costs & $\mathrm{TSC}_{\mathrm{M}}$ & $\mathrm{F}$ & $\begin{array}{l}\text { Manufacturers Total } \\
\text { Shortage Costs }\end{array}$ \\
\hline $\mathrm{Q}_{\mathrm{M}}$ & $\mathrm{V}$ & Manufacturers Order Quantity & $\vartheta$ & $\begin{array}{l}\text { Incremental Price } \\
\text { Ratio }\end{array}$ \\
\hline$\vartheta$ & $\mathrm{P}$ & $\begin{array}{l}\text { Incremental coefficient of social } \\
\text { responsibility }\end{array}$ & & \\
\hline
\end{tabular}

\subsubsection{Retailers Payoff Function}

In this part of research, payoff function of each player has been modeled. The retailer level has one member. To calculate the outcome of the retailer, the concept of the difference between revenues and costs has been used. Retailer's costs include the cost of ordering, holding and advertising spent on each product. The function of the product demand of the retailer is as follows, which depends on the variables of the retailers price, advertising, and social responsibility measurement index. Remark that, the type of demand function is exponential as Equation (11).

According to the results of Delphi-Fuzzy methods and structural interpretive modeling, the forced labor index as Equation (10) has been selected as the most influential indicator for measuring the social responsibility. This indicator is derived from the ratio of forced labor to the total number of employees at the desired level (Equation (12)), and therefore has a reverse relationship to demand. (Lee et al., 1996; Esmaeili et al., 2008; Huang \& Huang, 2010; Gurnani et al., 2007; Ma et al., 2013; Jia et al., 2013). 


$$
\begin{gathered}
D=\theta \cdot P_{R}^{-\alpha} \cdot C_{R}^{\beta} \cdot C S R_{M}^{\gamma} ; \\
C S R_{M}=B L_{\text {ratio }_{M}}=\left(\frac{B L_{M}}{L_{\text {tot } \mathrm{M}}}\right) ; \\
D=\theta \cdot P_{R}^{-\alpha} \cdot C_{R}^{\beta} \cdot B L_{\text {ratio }_{M}}^{-\gamma} .
\end{gathered}
$$

In Equation (13) D shows the demand, $\alpha$ presents the price elasticity of sensitive demand, $\beta$ denotes the impact factor of advertising, and $\gamma$ measures the impact of social responsibility efforts. The income of the retailer emanates from multiplying the profit margin in the product demand as Equation (14). The profit margin of a retailer Equation (16) is obtained from the difference in the wholesale purchase price from the sale price of the final customer (Equation (15)).

$$
\begin{gathered}
T R_{R}=G_{R} \times D ; \\
G_{R}=P_{R}-P_{M} ; \\
T R_{R}=\left[P_{R}-P_{M}\right] \times \theta \cdot P_{R}^{-\alpha} \cdot C_{R}^{\beta} \cdot B L_{\text {ratio }_{M}}^{-\gamma} .
\end{gathered}
$$

In Equation (21), the total cost of retailer including maintenance, ordering and advertising costs has been emanated based upon Equations (17) to (20).

$$
\begin{gathered}
T C_{R}=T_{M C}+T_{R}+T_{R} ; \\
T M C_{R}=D \times C_{R} ; \\
\operatorname{TOC}_{R}=C_{O_{R}} \times \frac{D}{Q_{R}} ; \\
T H C_{R}=\frac{1}{2} \times Q_{R} \times C_{h_{R}} \times P_{M} ; \\
T C_{R}=\left(\theta \cdot P_{R}^{-\alpha} \cdot C_{R}^{\beta} \cdot B L_{\text {ratio }_{M}}^{-\gamma} \times\left[C_{R}+\left(C_{O_{R}} \cdot Q_{R}^{-1}\right)\right]\right)+\left(\frac{1}{2} \times Q_{R} \times C_{h_{R}} \times P_{M}\right) .
\end{gathered}
$$

To illustrate retailers profits function, the $\pi_{R}$ symbol has been employed, which is derived from the difference income and retailers costs in Equation (22).

$$
\pi_{R}=T R_{R}-T C_{R}
$$

Retailer's restrictions include a positive profit margin and non-zero demand less than production capacity. Thus, the retailer model, with regard to the limitations and assumptions of the research and Equation (11) to (22), emanates as Equation (23):

$$
\pi_{R}=\left(\theta \cdot P_{R}^{-\alpha} \cdot C_{R}^{\beta} \cdot B L_{\text {ratio }_{M}}^{-\gamma} \times\left[\left[P_{R}-P_{M}-C_{R}\right]-C_{O_{R}} \cdot Q_{R}{ }^{-1}\right]\right)+\left(-\frac{1}{2} \times Q_{R} \times C_{h_{R}} \times P_{M}\right) \text {. }
$$

In this section, the concavity of the retailer function has been examined. Equations (24), (25), (26) have been used to check the concavity.

$$
\frac{\partial^{2} M A X \pi_{R}}{\partial^{2} Q_{R}}=-\frac{2 \times C_{O_{R}} \times C_{R}^{\beta} \times \theta}{B L_{\text {ratio }_{M}}{ }^{\gamma} \times P_{R}^{\alpha} \times Q_{R}^{3}}<0 ;
$$




$$
\begin{gathered}
\frac{\partial^{2} M A X \pi_{R}}{\partial^{2} P_{R}}=-\frac{2 \times \alpha \times C_{R}^{\beta} \times \theta}{B L_{\text {ratio }_{M}}{ }^{\gamma} \times P_{R}{ }^{\alpha+1}}-\frac{\left(\alpha \times C_{R_{m}}{ }^{\beta} \times \theta \times(\alpha+1)\right) \times\left(C_{R}-P_{R}+P_{M}+\frac{C_{O_{R}}}{Q_{R}}\right)}{B L_{\text {ratio }_{M}}{ }^{\gamma} \times P_{R}{ }^{\alpha+2}}<0 \\
\frac{\partial^{2} M A X \pi_{R}}{\partial^{2} C_{R}}=-\frac{2 \cdot C_{R}{ }^{\beta-1} \cdot \beta \cdot \theta}{B L_{\text {ratio }_{M}}{ }^{\gamma} \cdot P_{R}{ }^{\alpha}}-\frac{C_{R}^{\beta-2} \cdot \beta \cdot \theta \cdot(\beta-1)\left(C_{R}-P_{R}+P_{M}+\frac{C_{O_{R}}}{Q_{R}}\right)}{B L_{\text {ratio }_{M}}{ }^{\gamma} \cdot P_{R}{ }^{\alpha}}<0 .
\end{gathered}
$$

As presented, the retail profit function is concave toward the retail price, order quantity, and marketing efforts.

\subsubsection{Manufacturer Payoff Function}

In this section, the payoff function for the manufacturer is emanated. The manufacturer's income derives from the sale of the product minus its costs including purchasing raw materials from suppliers, product shortages, setting up the production line, production, ordering, holding, and reducing the proportion of the forced labor (Wang \& Tang, 2009; Oganezov, 2006; Chakraborty et al., 2010; Chang, 2008; Pentico et al., 2009; Jia et al., 2013; Amoozad Mahdiraji, Zavadskas, \& Razavi Hajiagha, 2015; Amoozad Mahdiraji, Govindan, Zavadskas, \& Razavi Hajiagha, 2014). The shortage is compensated by the use of delayed orders. The manufacturer has a warehouse for storing the final product. The total income of the manufacturer consists of multiplying the manufacturer's profit margin on the demand for the product as Equation (27). The profit margin of each manufacturer is derived from the difference in the wholesale price of the purchase and production costs and the cost of implementing the social responsibility in Equation (28). Total production and backlog costs besides manufacturer's total revenue are presented in Equation (29) to (31) respectively.

$$
\begin{gathered}
T R_{M}=G_{M} \times D=\left(P_{M} \times D\right)-T B C_{M}-T P C_{M} ; \\
G_{M}=P_{M}-C_{P}-C_{L}-\eta_{M} B L_{\text {ratio }_{M}} ; \\
T B C_{M}=C_{P_{M}} \times D=C_{P_{m}} \times \theta \cdot P_{R}^{-\alpha} \cdot C_{R}{ }^{\beta} \cdot B L_{\text {ratio }_{M}}{ }^{-\gamma} ; \\
T P C_{M}=C_{L_{M}} \times D=C_{L_{M}} \times \theta \cdot P_{R}^{-\alpha} \cdot C_{R}{ }^{\beta} \cdot B L_{\text {ratio }_{M}}{ }^{-\gamma} ; \\
T R_{M}=\left[P_{M}-C_{P_{M}}-C_{L_{M}}-\eta_{M} B L_{\text {ratio }_{M}}\right] \times \theta \cdot P_{R}^{-\alpha} \cdot C_{R}{ }^{\beta} \cdot B L_{\text {ratio }_{M}}{ }^{-\gamma} .
\end{gathered}
$$

The startup costs for the manufacturer includes the number of setup and the cost for each according to Equation (33) and similarly for ordering costs as Equation (34). The summation presents the total ordering and setup costs in Equation (35).

$$
\begin{gathered}
\operatorname{TOSC}_{M}=T O_{M}+T S_{M} ; \\
T S_{M}=C_{S_{M}} \times \frac{D}{Q_{M}} ; \\
T O_{M}=C_{O_{M}} \times \frac{D}{Q_{M}} ;
\end{gathered}
$$




$$
\operatorname{TOSC}_{M}=\left[C_{S_{M}}+C_{O_{M}}\right] \times \frac{\theta \cdot P_{R}^{-\alpha} \cdot C_{R}^{\beta} \cdot B L_{\text {ratio }_{M}}{ }^{-\gamma}}{Q_{M}} .
$$

The total cost of production includes the cost of production per unit of product multiplied by the amount of demand in Equations (36) and (38). It should be noted that the variable cost of production per unit of product is considered as a function of product demand. Therefore, by increasing the demand for the product by retailers, the variable cost of production for the corresponding product decreases with respect to the coefficient of influence of the scale $\delta_{M}$ in Equation (37) (Amoozad Mahdiraji et al., 2015) which is a type of benefits resulted from the increase in production.

$$
\begin{gathered}
\operatorname{TPC}_{M}=C_{L_{M}} \times D ; \\
C_{L_{M}}=u_{M} \times D^{-\delta} ; \\
T P C_{m}=u_{M} \times D^{1-\delta}=u_{M} \times \theta^{1-\delta_{M}} \cdot P_{R_{M}}^{-\alpha \cdot\left(1-\delta_{M}\right)} \cdot C_{R_{M}}^{\beta \cdot\left(1-\delta_{M}\right)} \cdot B L_{\text {ratio } M}{ }^{-\gamma \cdot\left(1-\delta_{M}\right),} \\
\text { if } 0<\delta_{M}\left\langle 1, u_{M}\right\rangle 0 .
\end{gathered}
$$

Total maintenance costs per manufacturer is presented in Equation (40) including final product storage costs that are calculated based on Equation (41). Where the cost is obtained in case the retailer's demand exceeds the capacity of production with multiplying the cost of each shortage in shortages quantity. The cost of each shortage unit is time-dependent and includes outstanding and compensated orders.. It is worth mentioning that the manufacturer has a gradual behavior as Equation (42) (Wang \& Tang, 2009; Oganezov, 2006; Chakraborty et al., 2010; Chang, 2008; Pentico et al., 2009). The summation of above mentioned costs leads to total related costs as Equation (43).

$$
\begin{aligned}
& \operatorname{TRC}_{M}=\mathrm{THC}_{M}+\mathrm{TSC}_{M} ; \\
& \mathrm{THC}_{M}=C_{h_{M}} \times \frac{\left(\varphi_{M} \times Q_{M}-B_{M}\right)^{2}}{2 \times \varphi_{M} \times Q_{M}} ; \\
& \operatorname{TSC}_{M}=\frac{C_{B_{M}} \times B_{M}^{2}}{2 \times \varphi_{M} \times Q_{M}} ; \\
& \varphi_{M}=1-\frac{D}{P C_{M}} ; \\
& T R C_{M}=\left(C_{h_{M}} \times \frac{\left(\left(1-\frac{\theta \cdot P_{R}^{-\alpha} \cdot C_{R}^{\beta} \cdot B L_{r a t i o_{M}}^{-\gamma}}{P C_{M}}\right) \times Q_{M}-B_{M}\right)^{2}}{2 \times\left(1-\frac{\theta \cdot P_{R}^{-\alpha} \cdot C_{R}^{\beta} \cdot B L_{r a t i o_{M}}^{-\gamma}}{P C_{M}}\right) \times Q_{M}}\right)+ \\
& \left(\frac{C_{B_{M}} \times B_{M}^{2}}{2 \times\left(1-\frac{\theta \cdot P_{R}^{-\alpha} \cdot C_{R}^{\beta} \cdot B L_{\text {ratio }_{M}}^{-\gamma}}{P C_{M}}\right) \times Q_{M}}\right) .
\end{aligned}
$$


The profit function of the manufacturer results from the differences of the total revenue and total cost of the manufacturer as Equation (44):

$$
\begin{gathered}
\pi_{M}=T R_{M}-T C_{M} ; \\
T C_{M}=T R C_{M}+T P C_{M}+\operatorname{TOSC}_{M} .
\end{gathered}
$$

According to the Equation (27) to (45), a general model of a manufacturer, taking into account its constraints, reveals as Equation (46):

$$
\begin{aligned}
& \pi_{M}=\left(\left[P_{M}-C_{P_{M}}-\left(u_{M} \times D^{-\delta_{M}}\right)-\eta_{M} B L_{\text {ratio }_{M}}\right] \times \theta \cdot P_{R}^{-\alpha} \cdot C_{R}{ }^{\beta} \cdot B L_{\text {ratio }_{M}}{ }^{-\gamma}\right)- \\
& \left(\left(C_{h_{M}} \times \frac{\left(\left(1-\frac{\theta \cdot P_{R}^{-\alpha} \cdot C_{R}^{\beta} \cdot B L_{\text {ratio }_{M}}{ }^{-\gamma}}{P C_{M}}\right) \times Q_{M}-B_{M}\right)^{2}}{2 \times\left(1-\frac{\theta \cdot P_{R}^{-\alpha} \cdot C_{R}^{\beta} \cdot B L_{\text {ratio }_{M}}{ }^{-\gamma}}{P C_{M}}\right) \times Q_{M}}\right)+\left(\frac{C_{B_{M}} \times B_{M}^{2}}{2 \times\left(1-\frac{\theta \cdot P_{R}^{-\alpha} \cdot C_{R}{ }^{\beta} \cdot B L_{\text {ratio }_{M}}{ }^{-\gamma}}{P C_{M}}\right) \times Q_{M}}\right)\right)- \\
& \left(\left[C_{S_{M}}+C_{O_{M}}\right] \times \frac{\theta \cdot P_{R}^{-\alpha} \cdot C_{R}^{\beta} \cdot B L_{r a t i o_{M}}^{-\gamma}}{Q_{M}}\right) .
\end{aligned}
$$

In this section, the concavity of the manufacture's profit function to decision variables has been examined. The following Equation (47) has been used to check the concavity as a case in point:

$$
\frac{\partial^{2} M A X \pi_{M}}{\partial^{2} B_{M}}=-\frac{\left(C_{B_{M}}+C_{h_{M}}\right)}{Q_{M} \times\left(1-\frac{\theta \cdot P_{R}^{-\alpha} \cdot C_{R}^{\beta} \cdot B L_{r a t i o_{M}}{ }^{-\gamma}}{P C_{M}}\right)}<0 .
$$

Obviously, the profit function of the manufacturer is concave.

\subsubsection{Best responses of players}

In game theory, each player has rationality and awareness; thus, will not be satisfied in the Nash game with less than their optimal level (Amoozad Mahdiraji et al., 2014). In this section, the best responses for each of the SC members, including the manufacturer and retailer has been designed based upon their decision variables from Equation (48) to (54). In order to find the optimal response, the derivation of payoff function of each player has been resulted based upon related decision variables (Amoozad Mahdiraji et al., 2014). The results are presented in Table 11.

Games can be cooperative or non-cooperative between manufacturer and retailer. In noncooperative mode, decisions are made in both Nash (Static) and Stackelberg (Dynamic). In non-cooperative games, decisions are made individually, players do not interact with each other; however, each player's decisions are made with respect to the movement of others. If the game is in the mode of Nash or static, no player is superior to the other, and the strength of each player is equal to the other in bargaining. In a Stackelberg or Dynamic game mode, one member is either the leader or ahead of the other (Amoozad Mahdiraji et al., 2015). 
Table 11. Best responses of retailer and manufacturer

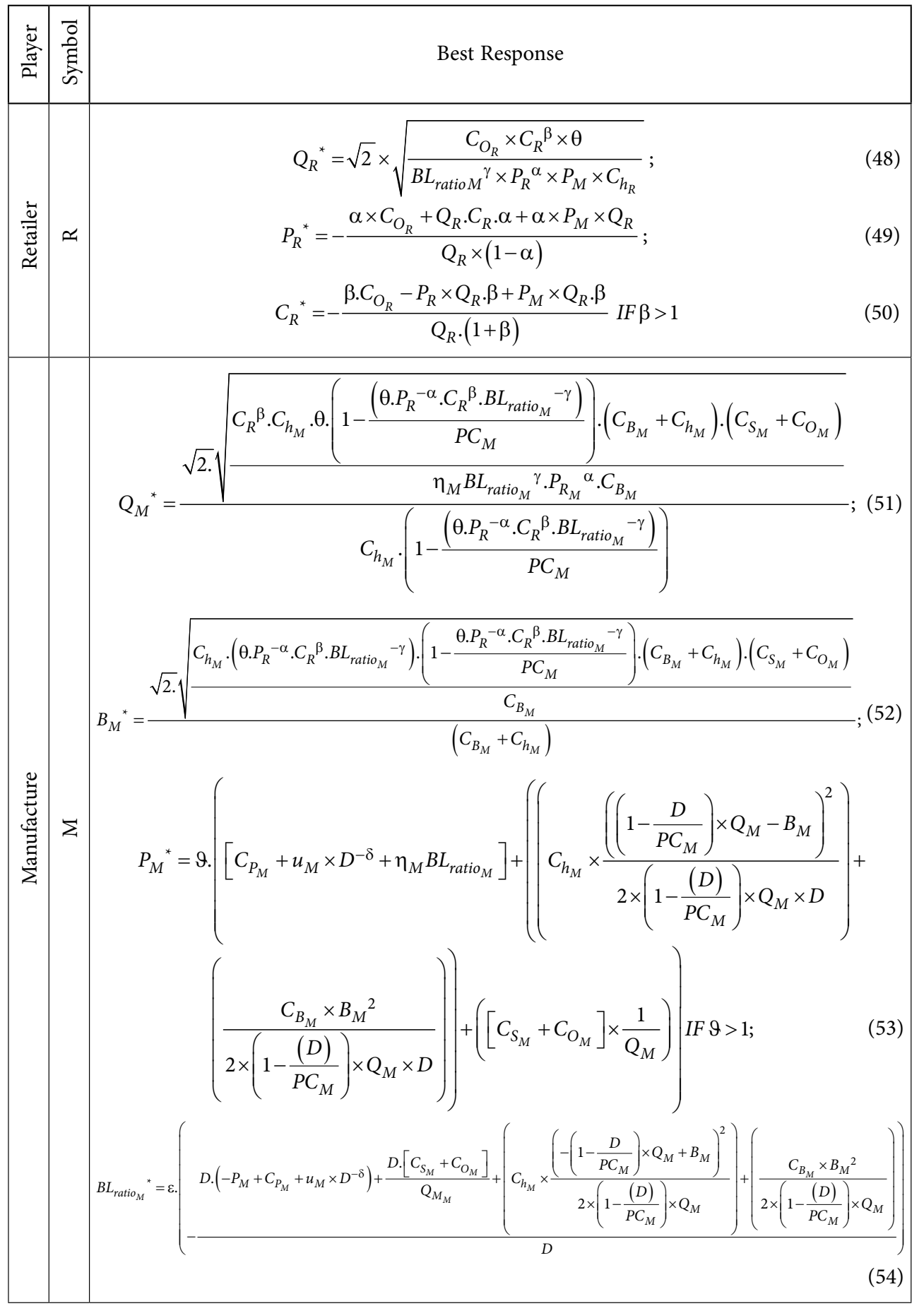




\subsubsection{The static non-cooperative games (Nash equilibrium)}

In decentralized games, players independently choose the values of their decision variables. This mode has been considered as the best player response in the previous section. In a centralized or merge mode, all members of SC jointly optimize their decision variables under a shared function. The decentralized non-cooperative Nash game is solely on the basis of the best responses of the manufacturer and retailer. In this case, the best responses are considered as constraints and solved. The decentralized model is resulted by solving Equations (13) and (48) to (58) conditional to Equations (55) to (58) as basic limitations:

$$
\begin{gathered}
D \geq 0 \\
P_{M}-\left[C_{P_{M}}+\left(u_{M} \times D^{-\delta_{M}}\right)\right] \geq 0 \\
D_{M} \leq P C_{M} \\
P_{R}-P_{M}>0
\end{gathered}
$$

\subsubsection{Non-cooperative dynamic games (Stackelberg game)}

In dynamic non-cooperative games, one of the members of SC is leader towards the other member. Decisions are made sequentially first by the leader and then by the follower. In this section, once the retailer and the manufacturer play the role of leader.

\subsubsection{Retailer's leadership}

In this type of model, maximizing the profitability of the retailer by taking into account the manufacturers best responses has been considered. Therefore, the objective function is maximizing the profit of the retailer and the limits of this function are the manufacturer's rationality and its best responses as model constraint. Considering the above conditions, the retailer's leadership model is resulted by solving Equations (59), (13) and (51) to (58).

$$
\begin{aligned}
& \operatorname{MAX} \pi_{R}=\left(\theta \cdot P_{R}^{-\alpha} \cdot C_{R}^{\beta} \cdot B L_{\text {ratio }_{M}}{ }^{-\gamma} \times\left[\left[P_{R}-P_{M}-C_{R_{M}}{ }^{\beta}\right]-C_{O_{R}} \cdot Q_{R}{ }^{-1}\right]\right)+ \\
& \left(-\frac{1}{2} \times Q_{R} \times C_{h_{R}} \times P_{M}\right) \\
& \text { s.t: } \\
& \text { Equations (13) and (51) to (58) }
\end{aligned}
$$

\subsubsection{Manufacturer leadership}

In this case, the manufacturer is the leader and the retailer is the follower. In this type of model, maximizing the manufacturer's profit regarding the retailer's best responses matters. Therefore, the objective function is the maximization of the manufacturer's profit and the limits are the manufacturer's rationality and its best responses as model constraint. Considering the above conditions, the manufacturer's leadership model is resulted by solving Equations (60), (13) and (48) to (50) and (55) to (58). 


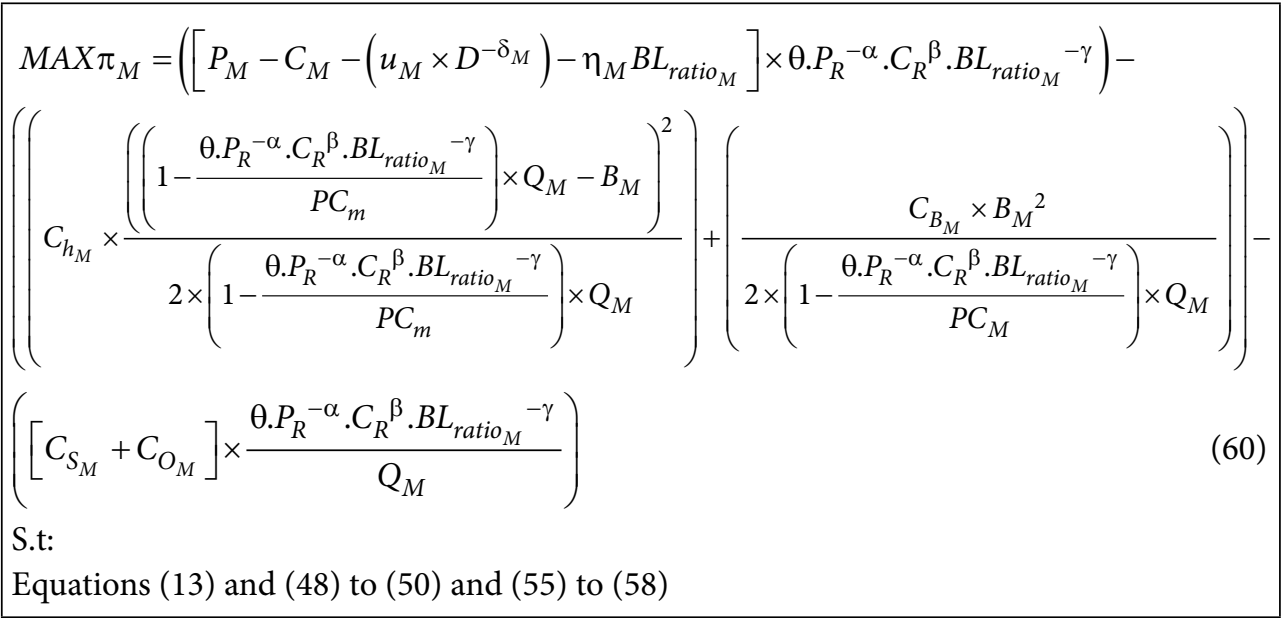

\section{Numerical example}

A numerical example for analyzing the proposed Nash and Stackelberg models are examined. The numeric data for the parameters is demonstrated in Table 12 based upon the assumptions of the considered two echelon supply chain and the notations mentioned in section 2 .

The results of the Nash and Stackelberg models are obtained using global non-linear programming in Lingo.17 and presented in Table 13. The initial results indicate that the manufacturer leadership of Stackelberg equilibrium brings the highest overall profit for the considered supply chain and the retailer leadership nearly equals the revenue and costs; thus, limited profit is occurred.

Considering the aim and the focus area of this research - the social responsibility - the behavior of the supply chain overall profit has been analyzed based upon the changes of the related factor. Hence, changes in forced labor ratio and its impact on overall profit of the supply chain has been investigated considering Nash and Stackelberg manufacturer leadership equilibriums in Table 14 and Figure 2 to 4.

Table 12. Initial information of numerical example

\begin{tabular}{|c|c|c|c|c|c|c|c|}
\hline$\theta$ & $\alpha$ & $\beta$ & $\gamma$ & $u_{M}$ & $\delta_{M}$ & $P C_{M}$ & $C_{P_{M}}$ \\
\hline 3 & 2.25 & 1.05 & 1.61 & 4 & 0.01 & 15 & 10 \\
\hline$C_{h_{M}}$ & $C_{B_{M}}$ & $C_{O_{M}}$ & $C_{S_{M}}$ & $C_{O_{R}}$ & $\varepsilon$ & $\vartheta$ & $C_{h_{R}}$ \\
\hline 0.5 & 1 & 4 & 7 & 5 & 1.1 & 1.1 & 0.15 \\
\hline
\end{tabular}

Table 13. Profit of different models

\begin{tabular}{|l|c|}
\hline \multicolumn{1}{|c|}{ Proposed Model } & Profit \\
\hline Nash Equilibrium & 19 \\
\hline Stackelberg Equilibrium - Retailer Leadership & 6 \\
\hline Stackelberg Equilibrium - Manufacturer Leadership & 96 \\
\hline
\end{tabular}


It is clear that the ascent of $\mathrm{BL}_{\text {ratio }}$ diminishes the overall profit in all three considered situations including Nash and Stackelberg models. Based upon limited profit for Retailers leadership mode, this situation has not been evaluated further. Figures 2 and 3 illustrate the effect of this factor more clearly of overall profit.

Table 14. Sensitivity analysis of social responsibility index on overall profit

\begin{tabular}{|c|c|c|}
\hline$B L_{\text {ratio }_{M}}$ & Nash & Stackelberg - manufacturer leadership \\
\hline 0.0001 & 4729660 & 31.2 \\
\hline 0.01 & 2845 & -3.5 \\
\hline 0.2 & 21.3 & -3.5 \\
\hline 0.4 & 6.1 & -3.5 \\
\hline 0.6 & 2.6 & -3.5 \\
\hline 0.8 & 1.2 & -3.5 \\
\hline 0.9 & 0.8 & -3.5 \\
\hline 1 & 0.5 & -3.5 \\
\hline
\end{tabular}

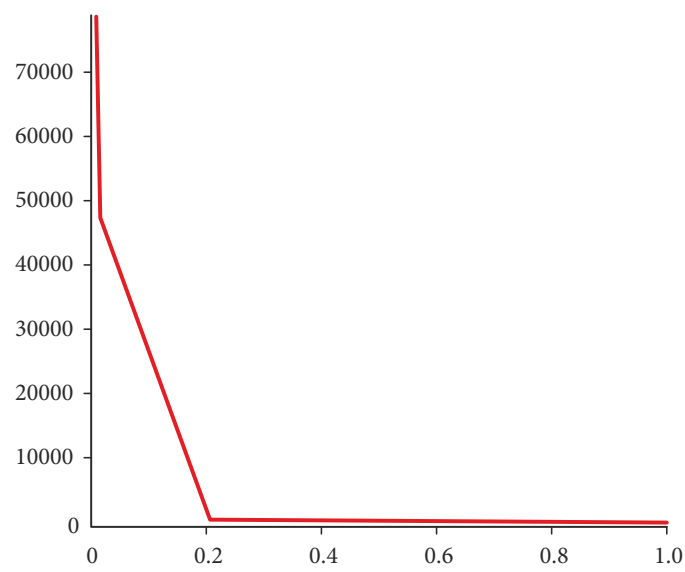

Figure 2. Nash model behavior on BL ratio changes

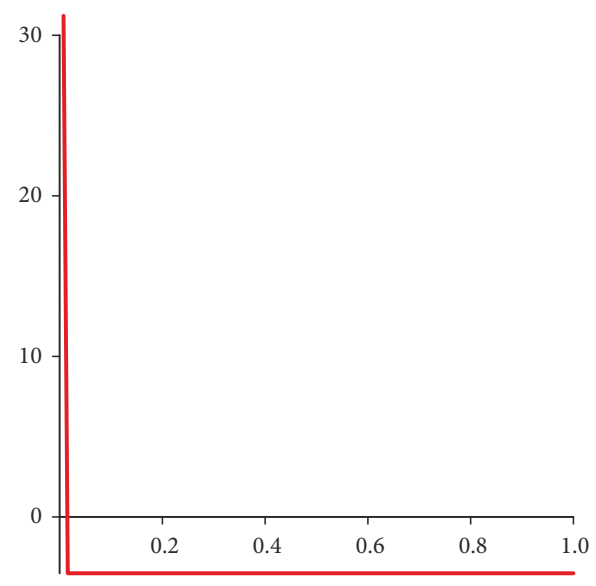

Figure 3. Stackelberg model behavior on BL ratio changes
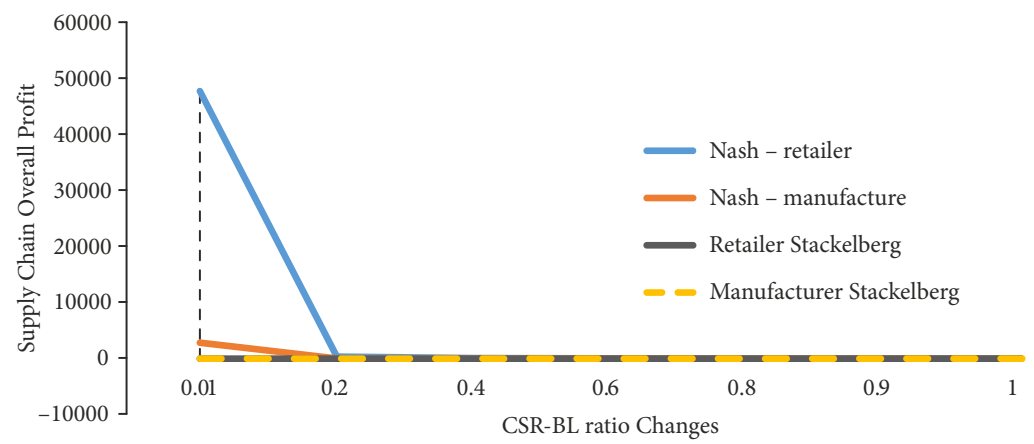

Figure 4. Nash and Stackelberg models Sensitivity analysis on BL ratio Changes 
To compare the considered modes and evaluate the overall profit behaviors upon $\mathrm{BL}_{\text {ratio }}$ changes, Figure 4 has been presented.

Considering Table 14 and Figures 2 to 4, it is worth noting here that among four proposed approaches, Nash equilibrium is more profitable than Stackelberg for the studied situation and designed supply chain. Moreover, based upon $\mathrm{BL}_{\text {ratio }}$ escalation, the overall profit of SC decreases in all proposed approaches, indicating the effectiveness of this criteria. For more than $20 \%$, this criteria will lead to zero or negative profit in all considered situations.

\section{Conclusions}

To cooperate or not is one of the most challenging issues in supply chain management era. If the supply chain is managed optimally, the entire profitability will be increased. Meanwhile, corporate Social Responsibility is defined as the social and ethical behavior of supply chain members against stakeholders such as shareholders, final customers, employees, and executives.

In this article, the manufacturer is responsible for the costs of social responsibility, and the retailer is responsible for the costs of advertising and marketing the final product. Additionally, the costs of shortages and incremental behavior are considered for the manufacturer. Therefore, considering the importance of coordination and conflict solution in the SC with regard to the social responsibility, this research has been designed to model and optimize the consequences of retailers and manufactures in complete information conditions.

Furthermore, the considered variables encompasses the cost resulting from the performance of corporate social responsibility, inventory and shortage, advertising and pricing in a two-level supply chain, consisting a manufacturer and a retailer. Identifying the quantitative variables for measuring the social responsibility using Delphi-Fuzzy methods and Interpretive Structural Modeling, modeling the profit function of each player, optimizing each players payoff functions according to the bargaining power of each member based on Nash and Stackelberg games, were all performed. As a result, among four proposed approaches, Nash equilibrium is more profitable than Stackelberg for the studied situation and designed supply chain. Moreover, based upon $\mathrm{BL}_{\text {ratio }}$ escalation, the overall profit of SC decreases in all proposed approaches, indicating the effectiveness of this criteria.

Considering non cooperative situation and deterministic nonlinear demand function as main limitations of this research, future researches can focus on presenting or analyzing coordination contracts and probabilistic demand functions. Comparing the results obtained from cooperative situation with non-cooperative circumstance leads to interesting results.

\section{References}

Ahi, P., \& Searcy, C. B. (2015). Measuring social issues in sustainable supply chains. Measuring Business Excellence, 19(1), 33-45. https://doi.org/10.1108/mbe-11-2014-0041

Akcay, E. C., Ergan, S., \& Arditi, D. (2017). Modeling information flow in the supply chain of structural steel components. Journal of Civil Engineering and Management, 23(6), 753-764.

https://doi.org/10.3846/13923730.2017.1281841 
Amoozad Mahdiraji, H., Shateri, H., Beheshti, M., \& Mokhtarzadeh, N. G. (2019). A comparison of buyback, rebate and flexible contracts in a seller-buyer supply chain. Transformations in Business \& Economics, 18(1), 109-127.

Amoozad Mahdiraji, H., Zavadskas, E. K., \& Razavi Hajiagha, S. (2015). Game theoretic approach for coordinating unlimited multi echelon supply chains. Transformations in Business and Economics, 14(2), 133-151.

Amoozad Mahdiraji, H., Govindan, K., Zavadskas, E. K., \& Razavi Hajiagha, S. (2014). Coalition or decentralization: a game-theoretic analysis of a three-echelon supply chain network. Journal of Business Economics and Management, 15(3), 460-485. https://doi.org/10.3846/16111699.2014.926289

Ashby, A., Leat, M., \& Hudson-Smith, M. (2012). Making connections: a review of supply chain management and sustainability literature. Supply Chain Management: an International Journal, 17, 497516. https://doi.org/10.1108/13598541211258573

Azapagic, A., \& Perdan, S. (2000). Indicators of sustainable development for industry: a general framework. Process Safety and Environmental Protection, 78(4), 243-261. https://doi.org/10.1205/095758200530763

Azar, A., Khosravani, F., \& Jalal, Y. (2013). Soft operation research. Tehran: management organization.

Cascio, W. (2010). Employment downsizing: causes, costs and consequences. In L. Stadtler, A. Schmitt, P. Klarner, \& Th. Straub, (Eds.), More than bricks in the wall: organizational perspectives for sustainable success (pp. 87-96). Gabler Verlag. https://doi.org/10.1007/978-3-8349-8945-1_9

Caulier-Grice, J., Davies, A., Patrick, R., \& Norman, W. (2012). Defining social innovation. In A deliverable of the project: "The theoretical, empirical and policy foundations for building social innovation in Europe, European Commission e 7th Framework Programme. Brussels: European Commission, DG Research.

Chen, S., \& Wu, W. (2010). A systematic procedure to evaluate an automobile manufacturer distributor partnership. European Journal of Operational Research, 205(3), 687-698.

https://doi.org/10.1016/j.ejor.2010.01.036

de Bloom, J., Kompier, M., Geurts, S., de Weerth, C., Taris, T., \& Sonnentag, S. (2009). Do we recover from vacation? Meta-analysis of vacation effects on health and well being. Journal of Occupational Health, 51(1), 13-25. https://doi.org/10.1539/joh.k8004

Debing, N., Kevin, L., \& Xiaowo, T. (2010). Social responsibility allocation in two-echelon supply chains: insights from wholesale price contracts. European Journal of Operational Research, 207(3), 1269-1279. https://doi.org/10.1016/j.ejor.2010.06.026

DPE. (2011). The Benefits of Collective Bargaining for Professional and Technical Workers. DPE Research Department, Washington, DC. Retrieved from http://dpeaflcio.org/programs-publications/issuefact-sheets/the-benefits-of-and technical-workers

Erol, I., Sencer, S., \& Sari, R. (2011). A new fuzzy multi-criteria framework for measuring sustainability performance of a supply chain. Ecological Economic, 70(6), 1088-1100. https://doi.org/10.1016/j.ecolecon.2011.01.001

European Commission. (2014). Social innovation. A decade of changes. Luxembourg: Publications Office of the European Union.

Fazlollahtabar, H. (2018). Operations and inspection cost minimization for a reverse supply chain. Operational Research in Engineering Sciences: Theory and Applications, 1(1), 91-107. https://doi.org/10.31181/oresta19012010191f

Goering, G. (2012). Corporate social responsibility and marketing channel coordination. Research in Economics, 66(2), 142-148. https://doi.org/10.1016/j.rie.2011.10.001

GRI. (2011). Sustainability reporting guidelines. Amsterdam, The Netherlands. 
Hanafizadeh, P., \& Mirzazadeh, M. (2011). Visualizing market segmentaition using self-organizing maps and fuzzy Delphi method-ADSL market of telecommunication company. Expert Systems with Applications, 38(1), 198-205. https://doi.org/10.1016/j.eswa.2010.06.045

Hassini, E., Surti, C., \& Searcy, C. (2012). A literature review and a case study of sustainable supply chains with a focus on metrics. International Journal of Production Economics, 140(1), 69-82. https://doi.org/10.1016/j.ijpe.2012.01.042

Hediger, W. (2010). Welfare and capital-theoretic foundations of corporate social responsibility and corporate sustainability. The Journal of Socio-Economics, 39(4), 518-526.

https://doi.org/10.1016/j.socec.2010.02.001

Hsueh, C. (2014). Improving corporate social responsibility in a supply chain through a new revenue sharing contract. International Journal of Production Economics, 151, 214-222. https://doi.org/10.1016/j.ijpe.2013.10.017

ICheme, O. (2002). The sustainability metrics: sustainable development progress metrics recommended for use in the process industries. Rugby, UK.

Jia, P., Amoozad Mahdiraji, H., Govindan, K., \& Meidute, L. (2013). Leadership selection in an unlimited three-echelon supply chain. Journal of Business Economics and Management, 14(3), 616-637. https://doi.org/10.3846/16111699.2012.761648

Jong, S., \& Slavova, K. (2014). When publications lead to products: the open science conundrum in new product development. Research Policy, 43(4), 645-654.

https://doi.org/10.1016/j.respol.2013.12.009

Ju, Q., Ding, L., \& Skibniewski, M. J. (2017). Optimization strategies to eliminate interface conflicts in complex supply chains of construction projects. Journal of Civil Engineering and Management, 23(6), 712-726. https://doi.org/10.3846/13923730.2016.1232305

Katsikea, E., Theodosiou, M., \& Morgan, R. (2014). Why people quit: explaining employee turnover intentions among export sales managers. International Business Review, 24(3), 367-379. https://doi.org/10.1016/j.ibusrev.2014.08.009

Klassen, R., \& Vereecke, A. (2012). Social issues in supply chains: capabilities link responsibility, risk (opportunity), and performance. International Journal of Production Economics, 140(1), 103-115. https://doi.org/10.1016/j.ijpe.2012.01.021

Kruse, S., Flysjö, A., Kasperczyk, N., \& Scholz, A. (2009). Socioeconomic indicators as a complement to life cycle assessment e an application to salmon production systems. The International Journal of Life Cycle Assessment, 14(1), 8-18. https://doi.org/10.1007/s11367-008-0040-x

Kuo, Y. F., \& Chen, P. C. (2008). Constructing performance appraisal indicators for mobility of the service industries using Fuzzy Delphi Method. Expert Systems with Applications, 35(4), 1930-1939. https://doi.org/10.1016/j.eswa.2007.08.068

Kwon, I., \& Milgrom, E. (2014). The significance of firm and occupation specific human capital for hiring and promotions. Labour Economics, 31, 162-173. https://doi.org/10.1016/j.labeco.2014.07.003

Lim, L., Chan, C., \& Dallimore, P. (2010). Perceptions of human capital measures: from corporate executives and investors. Journal of Business and Psychology, 25(4), 673-688. https://doi.org/10.1007/s10869-009-9150-0

Lopez, R., Chong, H.-Y., Moon, S., \& Wang, X. Y. (2017). Case study on subcontracting arrangements in the scaffolding supply chain of a Liquefied Natural Gas infrastructure project. Journal of Civil Engineering and Management, 23(8), 1136-1147. https://doi.org/10.3846/13923730.2017.1388277

Lukovac, V., \& Popović, M. (2018). Fuzzy Delphi approach to defining a cycle for assessing the performance of military drivers. Decision Making: Applications in Management and Engineering, 1(1), 67-81. https://doi.org/10.31181/dmame1801671 
Ma, P., Wang, H., \& Shang, J. (2013). Contract design for two-stage supply chain coordination: integrating manufacturer-quality and retailer-marketing efforts. International Journal of Production Economics, 146(2), 745-755. https://doi.org/10.1016/j.ijpe.2013.09.004

Maignan, I., \& Ferrell, O. C. (2004). Corporate social responsibility and marketing: An integrative framework. Journal of the Academy of Marketing Science, 32(1), 3-19. https://doi.org/10.1177/0092070303258971

Mani, V., Agrawal, R., \& Sharma, V. (2014). Supplier selection using social sustainability: AHP based approach in India. International Strategic Management Review, 2(2), 98-112. https://doi.org/10.1016/j.ism.2014.10.003

Modak, N., Panda, S., Mishra, R., \& Sana, S. S. (2016). A three-layer supply chain coordination in socially responsible distribution system. Review of Applied Management Studies, 14(1), 75-87. https://doi.org/10.1016/j.tekhne.2016.06.001

Modak, N., Panda, S., Sana, S., \& Basu, M. (2014). Corporate social responsibility, coordination and profit distribution in a dual-channel supply chain. Pacific Science Review, 16(4), 235-249. https://doi.org/10.1016/j.pscr.2015.05.001

Nematollahia, M., Hosseini-Motlagha, M., \& Heydarib, J. (2017). Coordination of social responsibility and order quantity in a two-echelon supply chain: a collaborative decision-making perspective. International Journal of Production Economics, 184, 107-121. https://doi.org/10.1016/j.ijpe.2016.11.017

Ni, D., Li, K., \& Tang, X. (2010). Social responsibility allocation in two-echelon supply chains: insights from wholesale price contracts. European Journal of Operational Research, 207(3), 1269-1279. https://doi.org/10.1016/j.ejor.2010.06.026

OECD. (2012). Sick on the job? Myths and realities about mental health and work. Paris.

Panda, S. (2014). Coordination of a socially responsible supply chain using revenue sharing contract. Transportation Research Part E: Logistics and Transportation Review, 67, 92-104. https://doi.org/10.1016/j.tre.2014.04.002

Panda, S. M. (2016). Exploring the effects of social responsibility on coordination and profit division in a supply chain. Journal of Cleaner Production, 139, 25-40. https://doi.org/10.1016/j.jclepro.2016.07.118

Panda, S., Modak, N., \& Cárdenas-Barrón, L. (2017). Coordinating a socially responsible closed-loop supply chain with product recycling. International Journal of Production Economics, 188, 11-21. https://doi.org/10.1016/j.ijpe.2017.03.010

Panda, S., Modak, N., Basu, M., \& Goyal, S. (2015). Channel coordination and profit distribution in a social responsible three-layer supply chain. International Journal of Production Economics, 168, 224-233. https://doi.org/10.1016/j.ijpe.2015.07.001

Podgorski, D. (2015). Measuring operational performance of OSH management system e a demonstration of AHP-based selection of leading key performance indicators. Safety Science, 73, 146-166. https://doi.org/10.1016/j.ssci.2014.11.018

Popovic, T., Povoa, A., Kraslawski, A., \& Carvalho, A. (2018). Quantitative indicators for social sustainability assessment of supply chains. Journal of Cleaner Production, 180, 748-768. https://doi.org/10.1016/j.jclepro.2018.01.142

Puška, A., Maksimović, A., \& Stojanović, I. (2018). Improving organizational learning by sharing information through innovative supply chain in agro-food companies from Bosnia and Herzegovina. Operational Research in Engineering Sciences: Theory and Applications, 1(1), 76-90. https://doi.org/10.31181/oresta19012010175p

Raj, A., Biswas, I., \& Srivastava, S. (2018). Designing supply contracts for the sustainable supply chain using game theory. Journal of Cleaner Production, 185, 275-284.

https://doi.org/10.1016/j.jclepro.2018.03.046 
Roca, L., \& Searcy, C. (2012). An analysis of indicators disclosed in corporate sustainability reports. Journal of Cleaner Production, 20(1), 103-118. https://doi.org/10.1016/j.jclepro.2011.08.002

Seuring, S., \& Müller, M. (2008). From literature review to a conceptual framework for sustainable supply chain management. Journal of Cleaner Production, 16(15), 1699-1710. https://doi.org/10.1016/j.jclepro.2008.04.020

Simoes, M., Freitas, C., Barbosa-Povoa, A., \& Carvalho, A. (2016). Social life cycle assessment e a framework for mid-and end-point impact categories (Working-paper \#1e2016). CEG-IST, Instituto Superior Técnico (Technical University), Portugal.

Strandberg, T., von Bonsdorff, M., Strandberg, A., Pitkala, K., \& Raikkonen, K. (2017). Associations of vacation time with lifestyle, long-term mortality and health related quality of life in old age: the Helsinki Businessmen Study. European Geriatric Medicine, 8(3), 260-264. https://doi.org/10.1016/j.eurger.2017.03.003

Szekely, F., \& Knirsch, M. (2005). Responsible leadership and corporate social responsibility: metrics for sustainable performance. European Management Journal, 23(6), 628-647. https://doi.org/10.1016/j.emj.2005.10.009

Uma, S. (2003). A study on training importance for employees of their successful performance in the organization. International Journal of Science and Research, 2(11), 137-140.

Working definition, ISO 26000 Working Group on Social Responsibility. (2007). Sydney.

Zavadskas, E. K., Šaparauskas, J., \& Antucheviciene, J. (2018). Sustainability in construction engineering. Sustainability, 10(7), 1-7. https://doi.org/10.3390/su10072236 